\title{
PROFIL PENGETAHUAN ANTIBIOTIKA AMOKSISILIN MASYARAKAT DESA BATU-BATU, KUTAI KARTANEGARA
}

\author{
Desten Prima $^{1}{ }^{* *}$, Lizma Febrina ${ }^{1,2}$, Rolan Rusli ${ }^{1,2, \dagger}$ \\ ${ }^{1}$ Laboratorium Penelitian dan Pengembangan Kefarmasian "Farmaka Tropis", \\ Fakultas Farmasi, Universitas Mulawarman, Samarinda \\ *Email :destenp@yahoo.com \\ ${ }^{2}$ Kelompok Bidang Ilmu Kimia Farmasi, Fakultas Farmasi, \\ Universitas Mulawarman, Samarinda \\ †Email : rolan@farmasi.unmul.ac.id
}

\begin{abstract}
Antibiotics are used to treat diseases of diseases caused by bacterial infection, and its use must be precisely and correctly to avoid bacterial resistance. Therefore it is necessary to know how an understanding of antibiotics by people in the village of Batu-Batu in Muara Badak, Kutai Kartanegara, especially antibiotics amoxicillin, and provide insight to the public about antibiotic amoxicillin. The method in this research use descriptive research design. The sampling method is random with 1755 years of age and it is distinguished by education level, gender and community work in the village of Batu-Batu sub district Muara Badak. According to result of this research, shows that knowledge levels of people in village of Batu-Batu are low to antibiotic amoxicillin, and it's influenced by the level of education and gender villagers at Batu-Batu village community in Muara Badak.
\end{abstract}

Keyword: Antibiotic, Amoxicillin, Knowledge Profile

\begin{abstract}
ABSTRAK
Antibiotika digunakan untuk mengobati penyakit-penyakit yang disebabkan oleh infeksi bakteri, dan penggunaannya harus tepat dan benar untuk menghindari resistensi bakteri. Oleh karena itu perlu diketahui bagaimana pemahaman antibiotik oleh masyarakat di desa Batu-Batu, Kutai Kartanegara khususnya antibiotika amoksisilin, serta memberikan wawasan kepada masyarakat mengenai antibiotika amoksisilin. Metode dalam penelitian ini menggunakan rancangan penelitian deskriptif. Metode pengambilan sampel adalah secara acak dengan umur 17-55 tahun dan dibedakan berdasarkan tingkat pendidikan, jenis kelamin dan pekerjaan masyarakat di desa Batu-Batu. Dari data yang diperoleh menunjukkan tingkat
\end{abstract}


pengetahuan masyarakat terhadap antibiotika amoksisilin rendah, dan dipengaruhi oleh tingkat pendidikan serta jenis kelamin masyarakat desa Batu-Batu.

Kata Kunci: Antibiotik, Amoksisilin, Profil Pengetahuan

\section{PENDAHULUAN}

Antibiotik adalah segolongan senyawa baik alami maupun sintetik, yang mempunyai efek menekan atau menghentikan suatu proses biokimia di dalam organisme, khususnya dalam infeksi oleh bakteri. Antibiotika yang paling banyak digunakan untuk kemoterapi infeksi bakteri ialah antibiotika golongan $\beta$-laktam, terutama penisilin dan turunannya. Salah satu turunan penisilin yang sering digunakan untuk pengobatan infeksi bakteri adalah amoksisilin [1].

Amoksisilin tersebar luas di pasaran, hingga warung-warung yang tidak memiliki ijin untuk penjualan obat keras juga memilikinya, sedangkan masyarakat lebih memilih lokasi yang dekat dengan tempat tinggal mereka untuk membeli obat. Karena kurangnya pengetahuan tentang amoksisilin, mereka tidak mematuhi akan penggunaannya secara tepat, akibatnya beberapa masyarakat tidak menghabiskan rasio dosis terapi antibotika ini, sehingga akan menyebabkan terjadinya resistensi mikroba terhadap antibiotika amoksisilin.

Tujuan dari penelitian ini adalah untuk mengetahui profil pengetahuan masyarakat di desa Batu-Batu mengenai antibiotika amoksisilin, serta memberikan wawasan kepada masyarakat tentang antibiotika amoksisilin.

\section{METODE PENELITIAN}

Penelitian ini dilakukan dengan menggunakan kuisioner yang berisi pertanyaan untuk mengetahui pemahaman masyarakat mengenai antibiotik khususnya amoksisilin [2]. Kuisioner yang dibuat kemudian disebarkan secara acak ke masyarakat Desa Batu-Batu Kecamatan Muara Badak, Kabupaten Kutai Kartanegara. Data yang diperoleh dari kuisioner kemudian diolah secara deskriptif untuk memperoleh profil pemahaman masyarakat mengenai antibiotik amoksisilin.

\section{HASIL DAN PEMBAHASAN}

Hasil penelitian ini menunjukkan bahwa masyarakat desa Batu-batu ratarata memiliki pengetahuan yang kurang terhadap antibiotika amoksisilin dimana terbukti tehadap jawaban kuesioner yang telah diisi menunjukkan pengetahuan yang rendah terhadap obat antibiotika amoksisilin. Kriteria dibagi kedalam 4 kategori yaitu berdasarkan jenis kelamin, umur, ptndidikan terakhir, dan pekerjaan.

Kategori pertama yaitu berdasarkan jenis kelamin. Kategori jenis kelamin melibatkan 56 orang sampel berjenis kelamin laki-laki, dan 52 orang sampel berjenis kelamin perempuan (Gambar 1). Berdasarkan data yang diperoleh didapatkan bahwa sampel berjenis kelamin laki-laki memperoleh skor rata-rata pemahaman mengenai antibiotik amoksisilin sebesar 53,86 \%. Sedangkan sampel 
berjenis kelamin perempuan memperoleh skor pemahaman sebesar $56.10 \%$. Arikunto [3] menyatakan bahwa skor dalam rentang dibawah 40 merupakan kategori tidak baik, rentang antara 40-55 merupakan kategori yang kurang baik, rentang 56-75 merupakan kategori yang cukup baik, dan rentang 76-100 merupakan kategori baik.

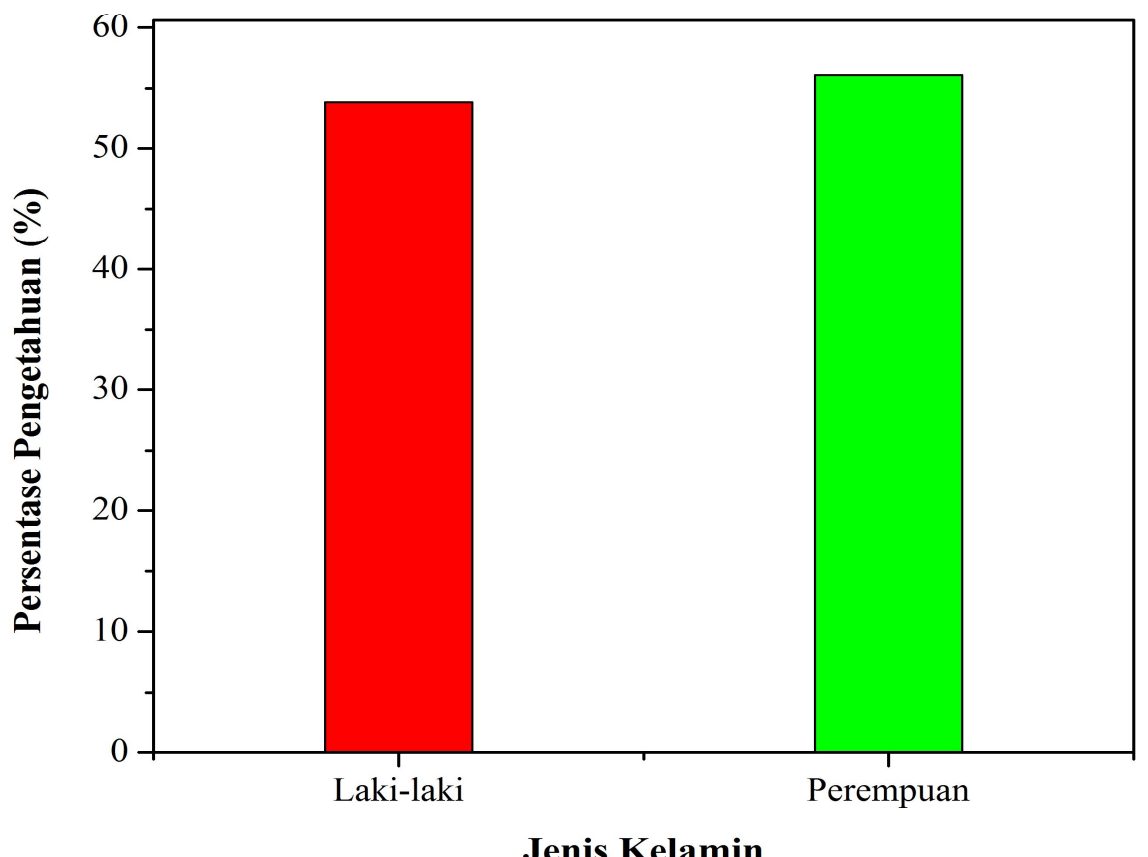

Gambar 1 Profil Pengetahuan berdasarkan jenis kelamin

Perbedaan antara pengetahuan antara laki-laki dan perempuan kemungkinan disebabkan oleh lebih pedulinya perempuan terhadap kesehatan yang mencakup obat-obatan, selain itu sumber informasi yang didapat perempuan kemungkinan lebih banyak karena fakta bahwa perempuan sering berinteraksi dan lebih aktif dari laki-laki dalam dunia sosial masyarakat seperti kegiatan PKK, dll.

Kategori kedua adalah berdasarkan jenis pekerjaan masyarakat di desa Batu-batu (Gambar 2). Beberapa jenis pekerjaan yang didapat adalah pelajar/mahasiswa dengan 24 sampel, petani/peternak dengan 26 sampel, PNS dengan 7 sampel, pegawai swasta dengan 19 sampel, wiraswasta dengan 9 sampel, dan IRT dengan 23 sampel. Pada pelajar/mahasiswa berdasarkan data diperoleh skor rata-rata pemahaman adalah $58,21 \%$, termasuk kategori yang cukup baik. Petani/peternak diperoleh skor rata-rata pemahaman adalah 50,81\%, merupakan kategori yang kurang baik. PNS diperoleh rata-rata skor pemahaman yaitu 57,80 $\%$ termasuk dalam kategori cukup baik. Pegawai swasta diperoleh rata-rata skor adalah 55,80\%, termasuk kategori kurang baik. Wiraswasta didapat skor rata-rata adalah $57,60 \%$, termasuk kategori cukup baik. Pada kategori pekerjaan yang terakhir yaitu ibu rumah tangga (IRT) didapat skor rata-rata adalah 53,87\%, 
termasuk kategori yang kurang baik. Dengan demikian dapat disimpulkan bahwa jenis pekerjaan tidak mempengaruhi tingkat pengetahuan masyarakat mengenai antibiotika amoksisilin.

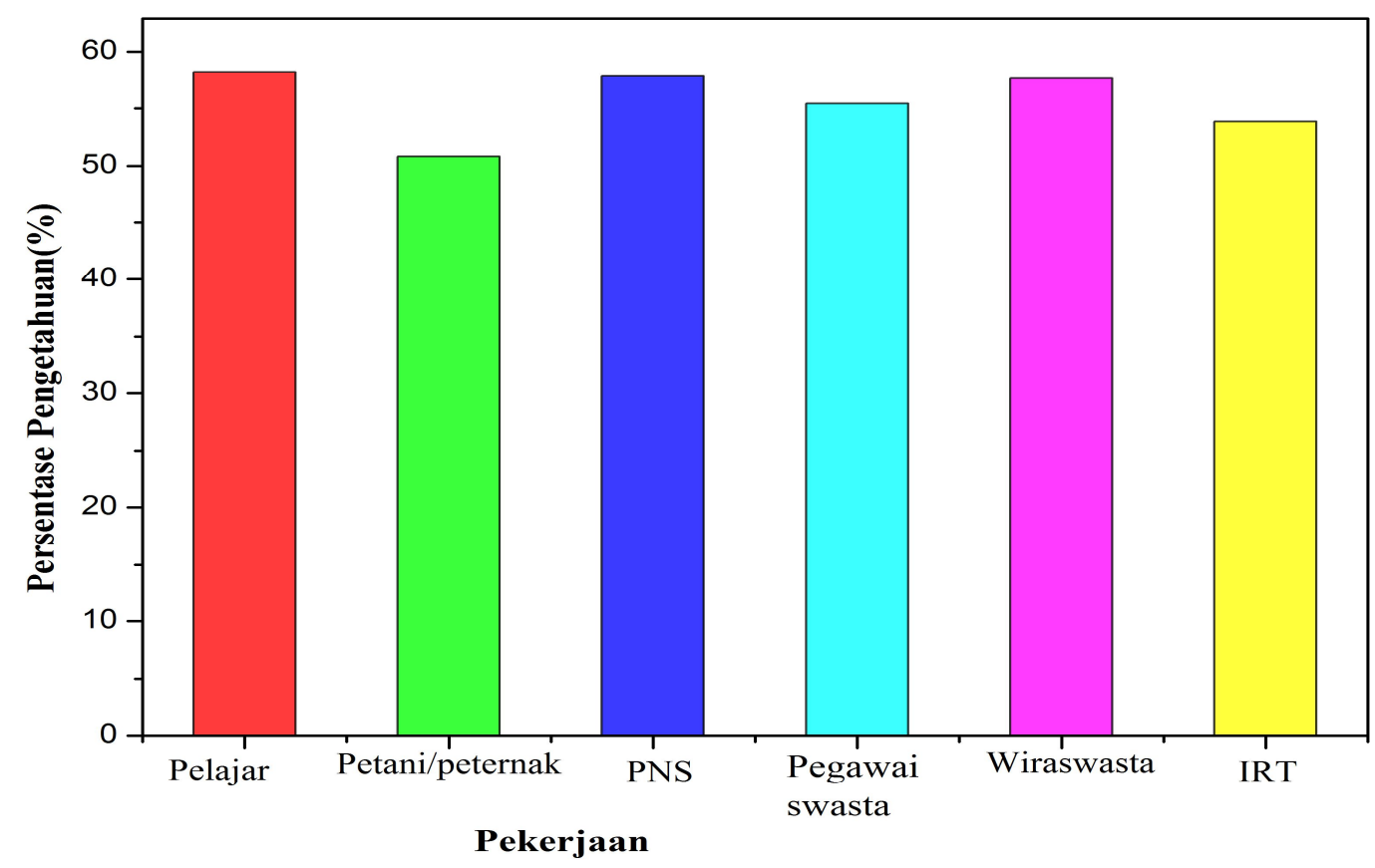

Gambar 2 Profil pengetahuan berdasarkan pekerjaan

Kategori ketiga adalah berdasarkan umur (Gambar 3). Umur merupakan salah satu faktor yang mungkin mempengaruhi tingkat pengetahuan seseorang mengenai antibiotika amoksisilin. Pada kategori usia pertama yaitu 17-25 tahun dengan jumlah sampel yang diperoleh adalah 37 orang, diperoleh skor rata-rata $56,28 \%$, termasuk kategori cukup baik. Pada kategori umur yang kedua adalah 2635 tahun yang merupakan masa dewasa awal, jumlah sampel yang diperoleh adalah 41 orang. Dari data yang didapat diperoleh skor $53,83 \%$, termasuk dalam kategori yang kurang baik. Pada kategori usia yang ketiga adalah 36-45 tahun, jumlah sampel yang diperoleh adalah sebanyak 19 orang. Jumlah skor rata-rata yang diperoleh dari data adalah 53,23\%, termasuk dalam kategori yang kurang baik. Pada kategori umur yang ke empat yaitu 46-55 tahun, jumlah sampel yang diperoleh adalah 10 orang. Dari data yang didapat, jumlah skor rata-rata pada usia ini adalah $57,37 \%$, termasuk dalam kategori yang cukup baik. 


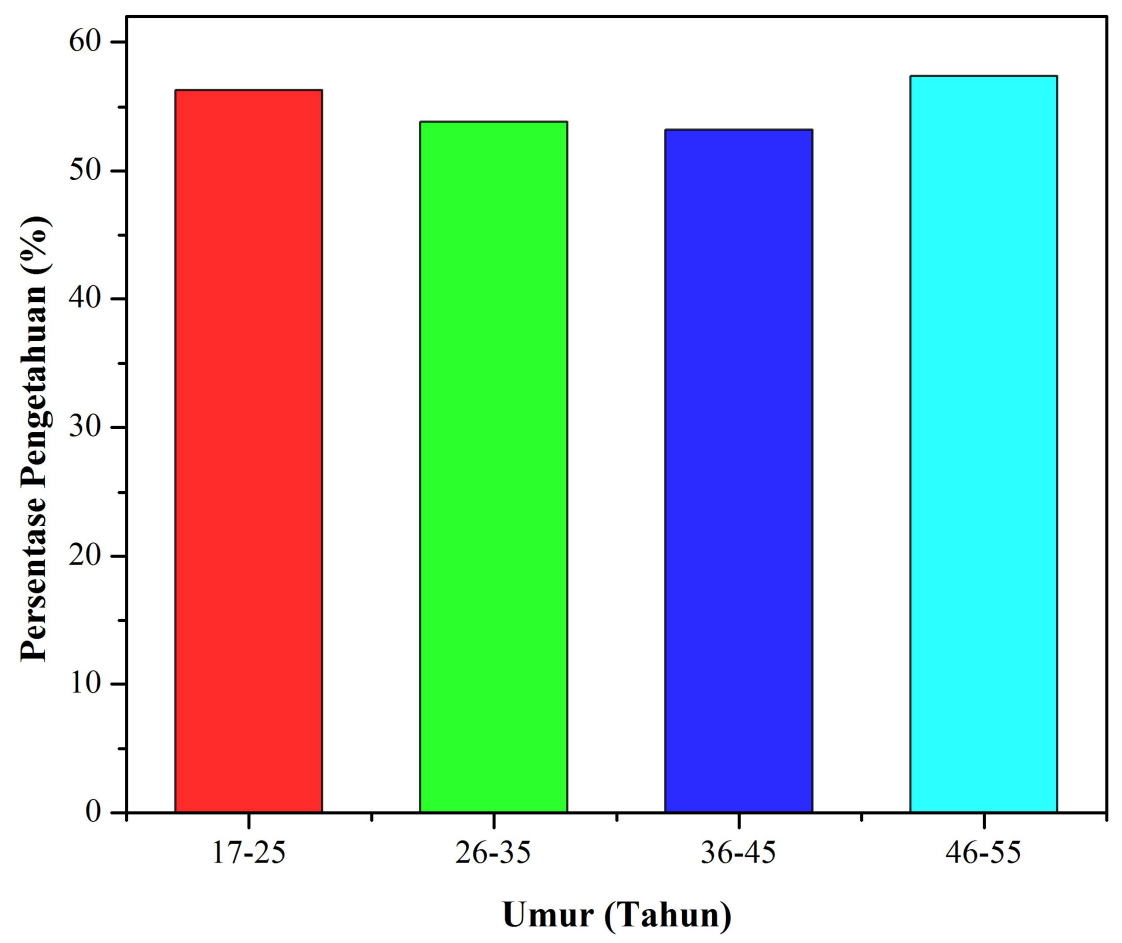

Gambar 3 Profil pengetahuan berdasarkan umur

Kategori keempat adalah berdasarkan pendidikan terakhir dari masyarakat di desa Batu-Batu kecamatan Muara Badak (Gambar 4). Pada kategori masyarakat yang tidak sekolah didapat sampel dengan jumlah 6 orang. Hasil skor rata-rata sampel adalah 48,68 \%, termasuk dalam kategori kurang baik. Pada kategori pendidikan SD, didapat sampel dengan jumlah 16 orang. Hasil data yang diperoleh adalah sampel ini memiliki skor rata-rata 50,82 \%, termasuk dalam kategori yang kurang baik. Pada kategori pendidikan terakhir SMP, jumlah sampel yang didapat adalah 10 orang. Hasil skor rata-rata yang didapat dari data untuk kategori ini adalah $50,79 \%$, termasuk dalam kategori yang kurang baik. Pada kategori pendidikan terakhir SMA, jumlah sampel yang diperoleh adalah 50 orang. Hasil rata-rata skor yang dimiliki oleh kategori ini adalah $56,57 \%$, adalah kategori yang cukup baik. Pada kategori pendidikan terakhir D3, didapat 2 orang sampel. Hasil yang diperoleh utnuk skor rata-rata sampel tersebut adalah 56,55\%, termasuk dalam kategori cukup baik. Pada kategori pendidikan terakhir S1, didapat jumlah sampel sebanyak 24 orang. Dari data hasil kuesioner yang telah dibagi, didapat skor rata-rata pada kategori ini adalah 57,43\%. termasuk dalam kategori cukup baik. 


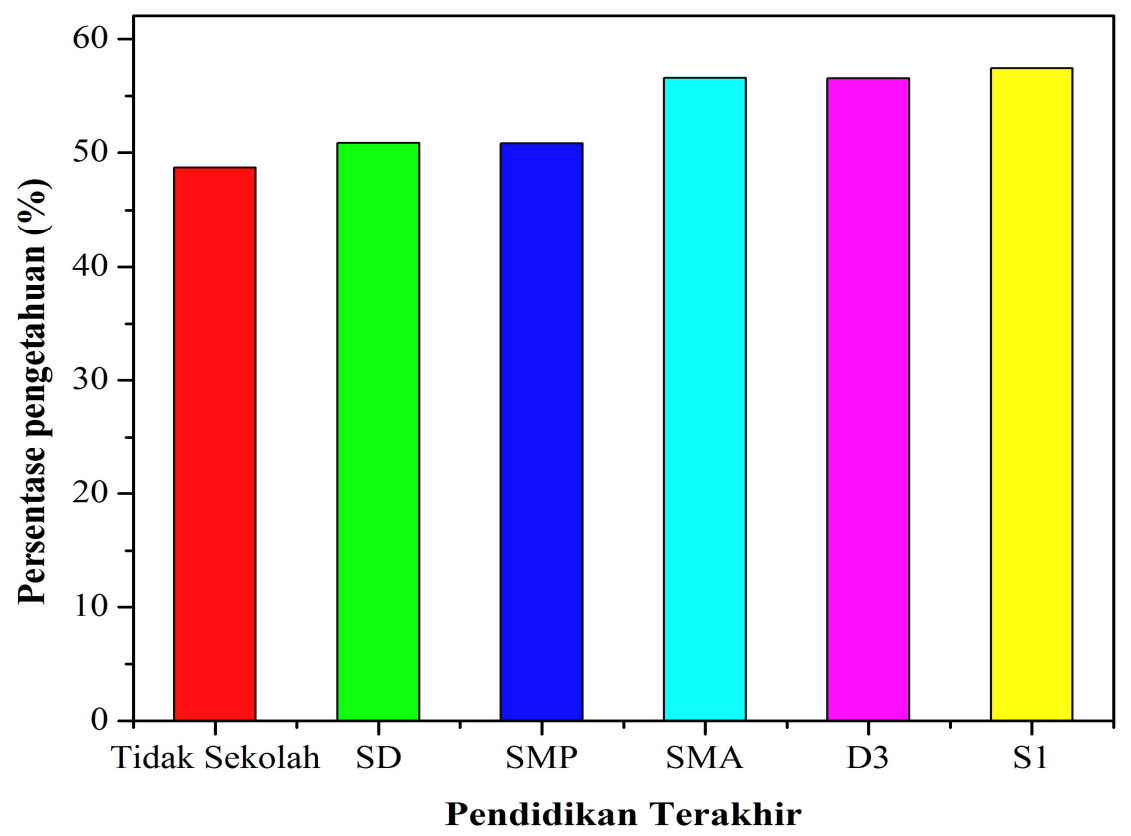

Gambar 4 Profil Pengetahuan berdasarkan Pendidikan Terakhir

Dari data pada Gambar 4 dapat dikatakan bahwa pendidikan terakhir berpengaruh terhadap pengetahuan masyarakat akan antibiotika amoksisilin, hal ini disebabkan karena pendidikan merupakan sumber pengetahuan bagi seseorang dimana didalamnya terdapat banyak materi yang membantu seseorang memahami sesuatu, begitu juga halnya dengan pengetahuan tentang antibiotika amoksisilin, semakin banyak sumber informasi semakin baik pula pengetahuan seseorang terhadap antibiotika amoksisilin. Jadi semakin tinggi pendidikan seseorang maka sumber informasi yang didapat akan semakin banyak serta kemampuan untuk menggunakan sumber informasi akan meningkat sehingga menyebabkan pengetahuan terhadap antibiotik amoksisilin baik.

\section{KESIMPULAN}

Berdasarkan hasil penelitian dapat disimpulkan bahwa masyarakat desa Batu-Batu memiliki pengetahuan yang rendah terhadap antibiotika amoksisilin, selain itu profil pengetahuan tidak dipengaruhi oleh jenis pekerjaan maupun umur, namun pendidikan terakhir serta jenis kelamin sedikit berpengaruh. 


\section{UCAPAN TERIMA KASIH}

Penulis mengucapkan terima kasih kepada masyarakat desa dan kepala desa Batu-Batu kecamatan Muara Badak yang telah berkontribusi dan telah mengijinkan penulis untuk melakukan penelitian ini.

\section{DAFTAR PUSTAKA}

[1] Pandean, F., Heedy, T., Lily, RG., 2013. Profil Pengetahuan Masyarakat Kota Manado Mengenai Antibiotika Amoksisilin. Jurnal Ilmiah Farmasi UNSRAT 2.(2) halaman 2

[2] Aspuah, S., 2013. Kumpulan Kuesioner dan Instrumen Penelitian Kesehatan. Nuha Medika: Yogyakarta.

[3] Arikunto, S. 1996. Prosedur Penelitian Suatu Pendekatan Praktek, Jakarta: Rineka Cipta 